\title{
WELFARE STATE POLICY MODEL AS A POVERTY REDUCTION STRATEGY IN THE WEST SUMATRA DISTRICTS AND CITIES
}

\author{
Azwar $^{1 *}$, Emeraldy Chatra $^{2}$, Zuldesni $^{3}$ \\ ${ }^{13}$ Department of Sociology, Faculty of Social and Political Science, Universitas Andalas, Padang, Indonesia. \\ 2 Department of Communication Studies, Faculty of Social and Political Science, Universitas Andalas, Padang, Indonesia.
}

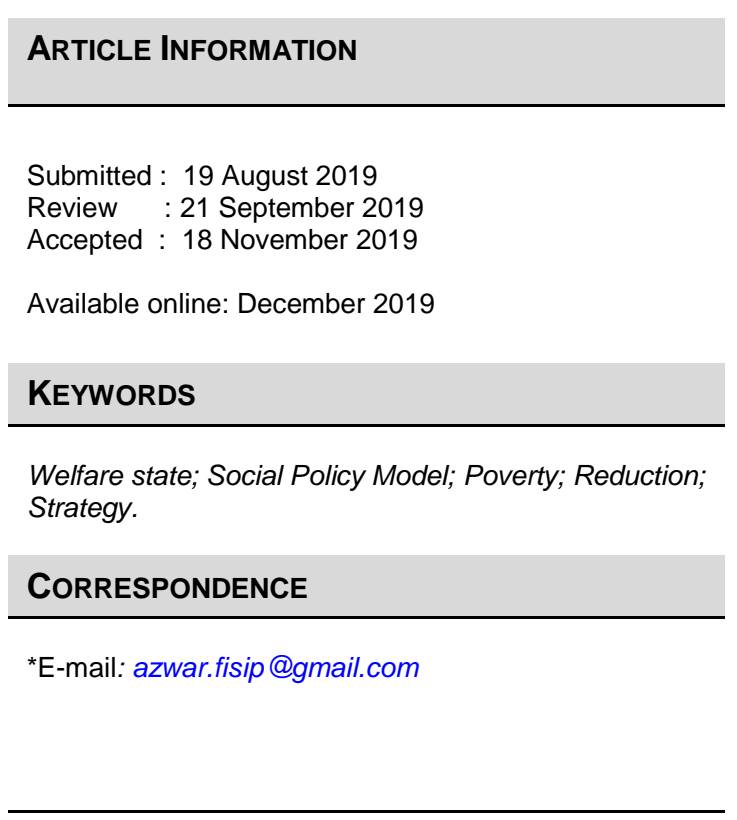

\section{A. INTRODUCTION}

T he head of the Central Statistics Agency (CSA) of the Republic of Indonesia released that in March 2018, the poverty rate in Indonesia had touched the one-digit figure of $9.82 \%$ or 25.95 million people. The highest number is still found in Java as many as 13.94 million and in Sumatra occupies the second largest number of 5.98 million, while the lowest number is in Kalimantan of 980 thousand. In the same month in 2018, the Head of CSA West Sumatra also said that for the number of poor people in the province amounted to $6.65 \%$ or 357,130 thousand people and nationally at rank 9 of 34 regions or below the order of North Maluku Province of $6,64 \%$. West Sumatra has three regencies with the highest number of poor people in the Mentawai Islands District at $14.67 \%$, West Pasaman District at $7.26 \%$, and South Solok District at $7.21 \%$. The lowest number of poor people is in Sawah Lunto City, which is $2.01 \%$, followed by Padang City at $4.74 \%$.

\section{A B S T R A C T}

Poverty is one of the social problems that the government can never completely solve. As a result, other, more significant social issues arise and cause social vulnerability, such as conflict and crime. As a province that is experiencing rapid growth in the last ten years, the West Sumatra find difficulty to overcome the number of poor people in several districts and cities. The research outcomes are the models and forms of social policy made by West Sumatra regencies and cities governments in improving the welfare of poor communities. It is also covering the constraints or obstacles to the implementation of social policy and the selection of welfare state models for the poor in some districts and municipalities of West Sumatra. This research is conducted qualitatively with a sociological approach that uses social perspective on searching and explaining social facts that happened to needy groups. Based on research conducted that the social policy model adopted by the government in responding to social problems in the districts and cities of West Sumatra reflects the welfare state model given to the poor. There is a strong relationship between the welfare state model and the form of social policy made by the government.

Although nationally, the poverty rate has decreased from double digits in 2017 (10.92\%) to 1 number in 2018 (9.82\%) the average district and city in West Sumatra reduce the poverty rate by $0.28 \%$. As in West Pasaman District, which is the largest and best palm oil plantation area, the results in Indonesia only experienced a decline in the number of poor people by $0.14 \%$. It is difficult to understand that the City of Padang as the Capital City of West Sumatra Province with LGR in 2016 reached $19.6 \%$ of the proportion of the APBD, the poor experienced an increase of $0.06 \%$, which at 2017 was $4.68 \%$ and in 2018 it became $4.74 \%$.

Poverty connotes unhealthy living conditions, according to McGillivray (2007), which is characterized by an inability to meet life's needs. When people were mentalization with a rope of poverty, power is needed both inside and outside. "Inner strength" manifests the ability of the poor to get out of the poverty loop. It is different from "external power," an intervention and facilitation carried out by other parties both individually and institutionally to open the poverty 
loop. Although poverty can have objective and subjective meanings and interpretations, the estuary of each purpose is how the quality of life can be a realization in the form of fulfilling life's needs. The government of one state institution has an essential role in providing strength to achieve a good quality of life or welfare. But the convergence between internal power and external power has a significant role so that people can get out of poverty or become wellbeing. For Harkness (2007), the welfare of the poor needs to be an expression in the form of happiness and maximum satisfaction.

However, according to Maolani (2019), the discrepancy between social policy and economic policy in solving poverty problems has a different strategy. The political system and social structure of a country as a dimension that influences the economic policy model a prosperous society. Meanwhile, Nurwanda (2019) sees that social policies in poverty programs are actively effecting the bureaucratic structure in a country. They saw from the case of the Raskin rice program in Cibanten Village, Cijulang District, Kabupaten Pangandaran. The program's policy implementation is not efficient because there are bureaucratic obstacles that are less than optimal. This situation is inseparable from the policy model adopted by the state in realizing a prosperous nation. The principle of "Good Governance," according to Ramdhani (2017), has not been carried out consistently but is still limited to discourse or narrative to the public. These principles include consistency, transparency, accountability, fairness, effectiveness, and efficiency. It means that the problem of poverty in the context of social policy using as a resource for a project for institutions and not to solve the problems of the poor themselves.

Other thoughts, the process of decommodification and decapitalization of the poor according to Gough in Kennett (2004), is the use of selfpotential to be used as an asset in increasing income to live prosperously by formal and nonformal institutions. Improving the welfare of the poor requires this process through policy interventions made by the state in the form of social guarantees and social protection (Spicker in Sutomo, 2011). This pattern has been carried out consistently by modern countries with the perfect welfare of the population before the country becomes a prosperous country (Spiro, 1983). According to King in Spiro (1983), resolving welfare issues must be integrated and simultaneous, cannot be part and segmented among institutions in implementing social policies in a state government. Wilensky also reinforced the same thought in Spiro (1983) and Flora in
Andre $\beta$ (2001), where the principle of applying "welfare" is that the government protects minimum standards in income, nutrition, housing, and guarantees of education to citizens as political rights and not as gifts or alms. It can do by providing a basic income guarantee, providing employment for everyone, supporting children from low-income families to go to college, reducing income differences.

The use of local institutions to boost the realization of a welfare state is one of the models developed in Indonesia. Local institutions designed in the form of the formation of Village Community Enterprises (VCE) in every village in Indonesia with economic activities. As research by Caya et al. (2019) in Belitung Regency concluded that the government program in promoting community welfare in villages through the VCE program has not been able to improve the social and economic community. This institution is only limited to making programs in the provision of education and public health infrastructure. Effectiveness and optimization of village institutions have not been able to realize the welfare of citizens, especially for the poor. As a result, the migration process took place to find a better place to live in the city. One of the jobs that many poor villagers enter when they reach the city is as a street beggar. Although various policies issued to prohibit becoming a beggar, but it can not inhibit. The principal reason, according to Basri and Yoserizal (2019), to survive as street beggars, is a factor in the economic needs of the family. The poor who move to the city uses all family members as a source of income by doing beggar work.

The poverty problem of determination from the level of community welfare, reduction, and increase in the number of poor people illustrates social policies implementation of the government. Lee Rainwater and Martin Rein in Spiro (1983) see poverty because of redistribution of income that does not work and includes the social services for the poor. Thus, the low and increasing decline in the number of poor people in West Pasaman District and the City of Padang between 2017-2018 is a shape of the social policy built by the government in realizing a prosperous state. If the government follows a pattern and model that is an inherent part of reducing the number of poor people, then the poverty rate quickly decreases. There will be no increase in the name of poor people, as experienced by Padang City if consistency and commitment in the use of public tax funds for social welfare programs.

Other cases were addressing the problem of poverty, such as those found by Wulandari and 
Rosfiantika (2018), which still leaves many improvements in policy. For example, in Bondowoso District, out of 12 districts running poverty programs, all of them have welfare problems. These problems include homeownership status, welfare levels, dropping out of school, access to electricity, quality of water sources, subsidized LPG access, sanitation facilities, working family members, and access to health services. The cause, according to Hurairah in Wulandari and Rosfiantika (2018), is 1). The program still orientation towards the economic aspect rather than a multidimensional aspect; 2). More compassion oriented than productivity; 3). Positioning the poor only as objects not as subjects in development, and 4). The government acts as the ruler rather than the facilitator. Not much different from the poverty program that applied to communities whose villages are affected by the construction of reservoirs in Koto Panjang, West Sumatra. That the welfare of the displaced households was better than in the old rural and that at the beginning of the displacement. It has been able to adjust themselves so that they can get out of the conditions of impoverishment that occurred during the initial transfer period. The average household income is above the Provincial Minimum Wage, and this condition does not show a good spread because only five villages from 12 research villages have an average salary above the PMW. There is no stable relationship (strong correlation) between income inequality and welfare because the correlation value obtained in this study is so low that it is not enough to prove the relationship between inequality and well-being for the case of Involuntary Resettlement Koto Panjang. (Adrianus et al., 2019)

The form of the model in question includes the model in implementation consisting of imperative models and indicative models. Then there are two models in the scope of the program, namely the selectivity model and the universal model. The sustainability of the implementation of the social policy has two models, namely the residual model and institutional model. Finally, the social policy model based on the problem and its objectives, which include categorical and comprehensive models (Suharto, 2005: 71-77). Through this paper which is the result of research trying to analyze the problem by finding forms of social policy made by the government of Padang City and West Pasaman District in improving the welfare of disadvantaged groups. Then it became very relevant in the analysis by finding the "welfare" policy model used by the two governments, including the obstacles faced in implementing social policies to accelerate the reduction of the number of poor people.

\section{B. METHOD}

T he method used in this study is a qualitative type of explanation by combining action research methods or participatory approaches in a wholeness construction to achieve the research objectives. Through this method has resulted in the identification of policies and includes a comprehensive model of the Welfare-state relating to the program to reduce the number of low-income families.

The stages of the research were initiated by identifying and analyzing various social policies originating from the center. Those created the regions themselves, including private and NGO programs aimed at low-income families in Pasaman Barat and Padang. Furthermore, classifying policies that are oriented to reduce the number of low-income families - documenting studies in various agencies that are relevant to the program to reduce the amount of low-income families, including conducting literature studies, direct observation, in-depth individual interviews. Through this method, information obtained on the obstacles that occur in implementing policies by stakeholders such as the Local Device Organization (LDO) that are responsible for needy families. Then the last one comprehensively conducts theoretical discussions to find the model of social policies implemented by district and city governments in low-income families.

This research carried out ethical and emotional analysis techniques, where, through this technique, the researcher immediately became the instrument of study, meaning that the researcher quickly collected data using interviews and observation methods. Analysis has begun since the data collection process in the field or from the interview and observation process. Therefore, in this study, data analysis was carried out by describing the information provided by the informant. Then the researcher interpreted the information provided.

\section{RESULT AND DISCUSSION}

\section{Local Government Social Policy in Poverty Programs}

$n$ the years of 2018 , that cannot avoid at this time are that the population classified as weak still reaches $7.26 \%$ in West Pasaman District while in Padang City is $4.74 \%$. Compared to the previous year, the poverty rate for West 
Pasaman Regency decreased by $0.14 \%$, but what was unusual for the City of Padang was an increase in the number of poor people by $0.06 \%$. This issue arises undoubtedly cannot separate from the policies carried out by the two governments through social programs oriented towards the welfare of the poor. The government action is proper in the context of implementing standard procedures, according to Gough in Kennett (2004: 240-241). The West Pasaman District Government and Padang City have taken action in the sense of meeting the needs of the poor, encouraging their potential, including supporting the active involvement of the community in realizing that prosperity. Like running a Healthy Indonesia Card program (HIC) and a Smart Indonesia Card (SIC) for treatment and educational help for the poor.

The program owned by the Regency and City Governments is a form of replication of the poverty reduction program created by the central government. Local governments only follow programs designed nationally in resolving national issues, namely reducing the number of poor people. Program funding comes from the central and regional governments in the form of budget priorities to make the federal program a success. In the context of poverty alleviation, the six programs mentioned above can grouping into three clusters, namely Cluster $I$ is a Poverty Reduction Program for Family-Based Integrated Social Assistance, Cluster II is a Poverty Reduction Program Based on Community
Empowerment, and Cluster III is a Poverty Reduction Program Based on Increasing Economic Capacity \& Revenue.

The social policies carried out were not limited to the two programs alone, the poor also received income guarantees (through the FHP), housing (UHP), assistance in need for rice (the Rastra program). All forms of social policy are manifestations of the government's obligation to actualize the rights of the poor to obtain social protection into a prosperous life (Spicker (2000: 151-154). It does at the individual level (providing cash assistance and scholarships including medical expenses), and group level (forming a joint business group-JBG) In the context of the scope of the policy carried out by the two governments, it has been included in social policy issues as mentioned by Lerner et al. (2006) which emphasizes on the poor, housing, health and opportunities in education, employment and non-discrimination, it means that the governments of West Pasaman Regency and Padang City as heterogeneous societies do not distinguish between ethnicity and religion in implementing social programs, Clasen stated the same thing in Kennett (2004: 93-95) that program implementation social is an expression of the government in regulating significant plans for the public such as income security, housing, health, and social services. This policy aims at guaranteeing or increasing welfare in the opportunity of human life.
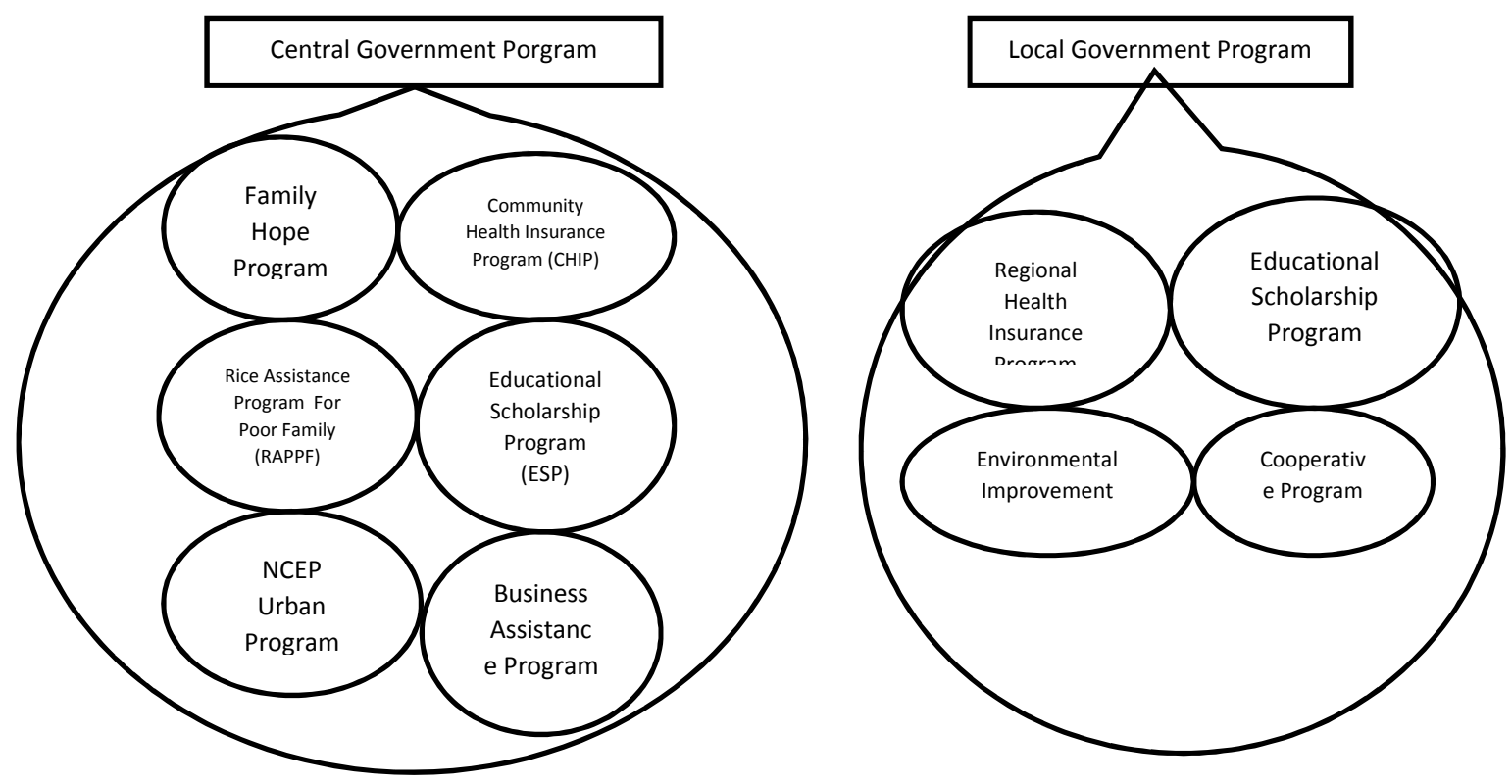

Fig. 1 Comparison Of The Central Government Poverty Program With Local Government

Based on figure 1, the various types of National Community Empowerment Programs
(NCEP) programs that are passed down by the central government to Regencies and Cities in 
West Sumatra, where the form of the application has determined only the implementation or type of activities based on the capacity and environmental conditions of the community. Therefore, the NCEP included in cluster II categorized as an imperative social policy. Then it is indicative because the targets or targets of the schedule determined by the central government and implemented through assistance from non-governmental organizations. It means that the government has outlined policy objectives, while the implementation is carried out entirely by the community (NGOs or social organizations), and this model often referred to as participatory policy. The Islamic Financial Services Cooperative (IFSC)-Baitul Mal Wattamwil (BMT) program is included in group III, namely providing stimulant funds developed in the form of joint ventures or the kind of savings and loans.

Interestingly this program's target group is the poor or residents who have small or microbusinesses - this program categorized in Padang City Government policy as a form of indicative and selectivity systems. As a symbolic policy, this program determined by the government, and then the poor or micro or small entrepreneurs given access to borrow funds that are sharia cooperatives.
The still high number of poor people in Pasaman Barat Regency and Padang City is a determination of failure in the implementation of social policies. Although the government already has clear targets and targets of the plan, it has not implemented an integrated social system. According to Edwar III in Widodo (2006: 96-110), four factors are integrated and interrelated in the successful implementation of social networks, namely (1) communication, (2) resources, (3) disposition, (4) bureaucratic structure. These four factors do not run simultaneously and tend to be partial in implementing social policies. Poor people get information through information dissemination conducted by officers in an unclear manner about the program they will receive. So that health and education assistance programs in the form of $\mathrm{HIC}$ and SIC are considered by the poor to be valid for life. Including direct cash assistance through the FHP program is understood as the same as a form of almsgiving. As a result, the poor did not make the assistance as a stimulant in stepping up to change lives to become more prosperous. But it leads to reckless living behavior by utilizing support for secondary needs. This situation arises not apart from the resources in running the program which is not competent. That is, placing people who do not have the ability in the program, such as putting healthcare workers in the social field.

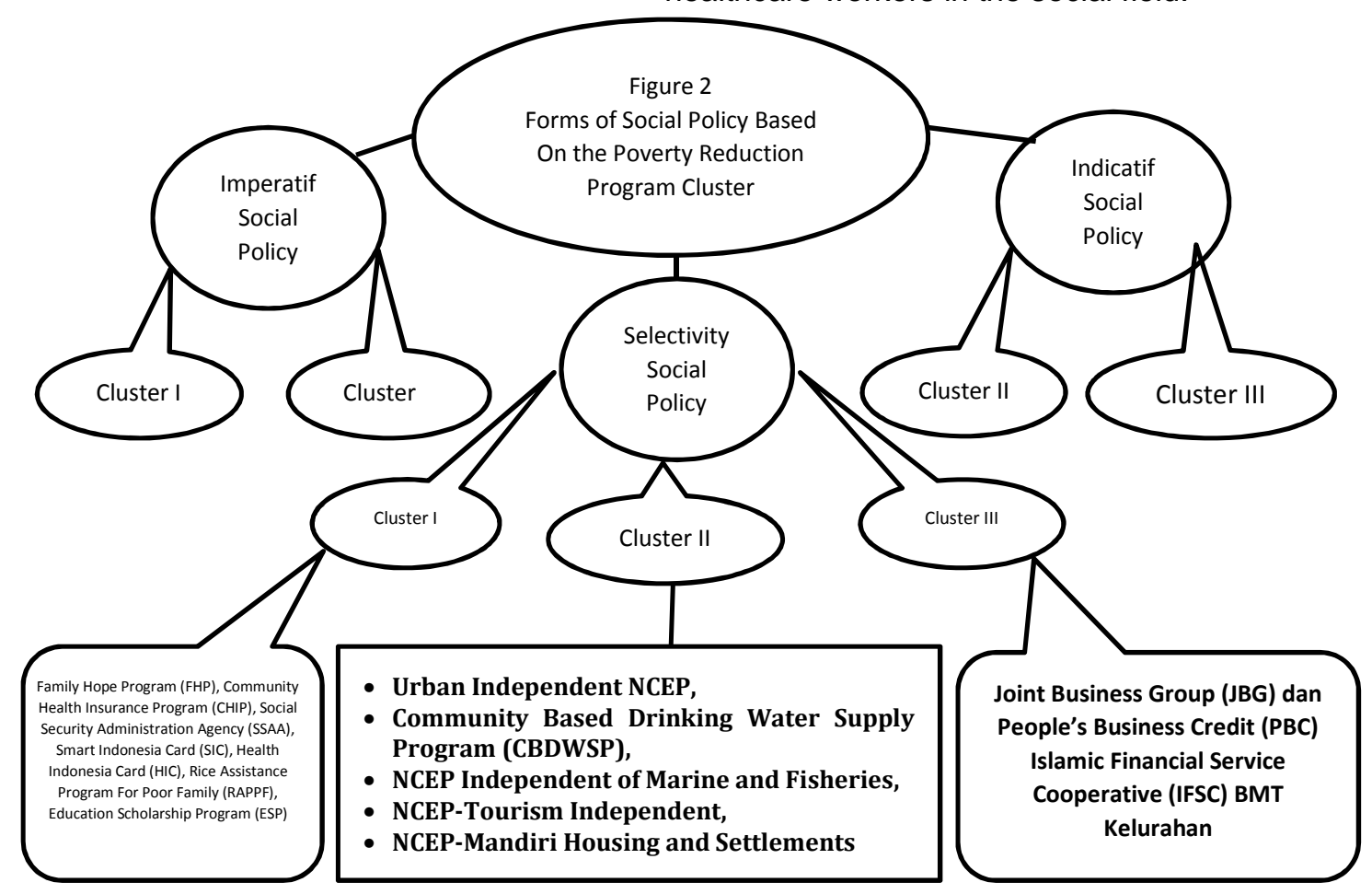

Fig. 2 Forms of Social Policy Based On the Poverty Reduction Program Cluster 
Edwar III further explained that the mistake in placing resources due to improper disposition factors. Many program implementers are not severe and severe because they are concerned that the person will not be in that position for a long time, including the also has no competence. Like knowledge, understanding, and objective or neutral and the form of intensity in carrying out policies is an essential part of placing people in a position (Mater and Horn in Widodo, 2005: 105). Local device organizations (LDO) which not synergized are also the cause of failure in reducing poverty. Including LDO, who have the main task of not being given high authority in making the program, but on the contrary, the LDO that is not directly related has a program that is a little touch in reducing the population. Such as the Office of Social Affairs and the Health Service have a small budget for poverty alleviation programs while the Department of Public Works has a huge budget. Only $1 \%$ of the Locally-Generated Revenue (LGR) for the budget given to the two agencies in carrying out its function as the "leading sector" of poverty alleviation programs.

\section{Model of Implementation of Social Policy in Poverty Programs}

The poverty program implemented by the governments of West Pasaman Regency and Padang City includes programs from regional centers and programs. The central government program consists of the Family Hope Program (FHP), Jamkesmas in the form of the Healthy Indonesia Card (HIC) program, the Smart Indonesia Card (SIC), the Unqualified Home Program (UHP), and the Prosperous Rice (Rastra). Then the regional government lowers programs such as Regional Health Insurance $(\mathrm{RHI})$, UHP, Sanitation, Electricity. The plan from the central government has become "given" to the local government because the objectives, types, sources, and forms of services determined while the local government only implements them. Similarly, the regional program is complementary to the limitations of the mayor plan to reach targets from those who receive plans from the central government. Like the UHP and $\mathrm{RHI}$ programs made by the local government because the number of program recipients limited from the central government, the regional government makes the same follow-up program for the regions.

Poor people who receive poverty programs have done with a pattern of selectivity where social services provided to low-income citizens, parents who do not have permanent jobs, including access to education. The program is determined using poverty testing instruments and needs tests. This model, according to Suharto (2005: 71-77), is called the social policy model of selectivity. Using the model described by Suharto, poverty programs implemented by the governments of West Pasaman District and Padang City are a combination of several models. First, using a model of social imperative and indicative policy, this is indicated by the government determining the form of programs that will be received by the poor. Then the suggestive model, where the central and regional governments outline the poverty program, the implementation is carried out entirely by the community or non-governmental institutions. As with the NCEP, it is a program from the central government, but it implemented by self-help groups formed by themselves.

The other model applied is a definite and comprehensive social policy model in the absolute model of the government of West Pasaman Regency and Padang City, focusing on the main problems that cause poverty, such as the economy, education, and health. It also includes implementing a comprehensive social policy model that is making social policies that pay attention to the interrelationship between the factors that influence it. There is a program cycle for the poor. The implementation of the FHP program through the provision of cash is directed to finance maternal health during pregnancy, meeting basic needs. If a sick person gives birth to a healthy baby will get a smart generation, FHP assistance used for educational purposes.

Policies made by the District and City governments in West Sumatra in poverty alleviation programs have guided the application of the welfare state model in providing services to the community. All existing and ongoing programs reflect imperative social policies, indicative social policies, and selective social policies. The three forms of social policy balanced in carrying out clusters of poverty reduction programs. Such as in group I, which focuses on conditional cash transfer and unconditional cash transfer programs. The targets and targets of this program are through the provision of conditional and unconditional cash transfers to poor communities. This program not be developed for non-poor community groups. Then the application has been determined, and the poor only take "granted for granted" what has been determined by the government. Impoverished households that receive the FHP program are required to utilize cash assistance in the health and education sectors. Low-income families must not use capital for business or buy work equipment. 
The above policy, if understood in the perspective model of a welfare state, is included in the residual model and the minimal model. It the better welfare state model is universal in the sense that the country has a responsibility for the welfare of its citizens both from the rich and the poor- forms of protection provided by the country ranging from clothing, shelter, food, health, and education. The state guarantees the health and education of its citizens, including proper housing, there are no citizens who are malnourished or not eating, or there are no citizens who do not get adequate training. All are under the responsibility of the state. It is a welfare state model that is ideal for applying to a country. Currently, the only one that can affect that model in Switzerland. Of course, the application of this model supported by the country's ability to provide the budget to help the policy. The city of Padang, as part of the Indonesian government system, shows more capacity to carry out the minimum and residual welfare state model. It could also be in the form of a welfare state corporation model or based on the scheme where the community members work. If a citizen works in a private company, then the one who guarantees his welfare is a private company; if he works in the government, then social security is obtained from the government. The fact is that not all corporate institutions provide social security for their workers, especially corporate organizations that are still small scale.

\section{Constraints to Implementing Social Policy in Poverty Programs}

Comprehensive and integrative forms of policy can reduce poverty rates quickly, including commitment and consistency in implementing the policy model. The increasing and number of poor people in Pasaman Barat Regency and Padang City due to several factors. These factors are relevant to what was stated by Edwar III in Widodo (2005) there are four factors, namely communication, resources, disposition, and bureaucratic structure.

Understanding of programs provided by the government to the poor is not able to change the behavior of life for the better. It is due to the communication that built-in introducing the program by the government to the recipients to highlight the formality and quantity and ignore the quality of communication. The socialization meeting measured its activities from the time of the meeting, evidenced by the attendance list by the poor, but ignored the understanding of the program for the poor. Besides, the resource factor is also the main trigger for the increasing number of poor people. Capital resources are the principal reason given, where local governments do not have sufficient budget to reduce the number of poor people. So that dependence on poverty programs from the central government is very high, and few programs raised from local governments. As a result, regions have a strategy to be able to obtain central funds by maintaining the amount of poverty so that they always included in the recipients of poverty programs from the center.

Another obstacle in implementing social policy models is the disposition factor, meaning that institutions or LDO that are relevant to poverty programs not occupied by people who have competence and commitment. So that LDO leaders often work not seriously because of career uncertainty in holding positions in LDO. The difficulty of keeping from running the social policy model is because the bureaucratic structure or inter-LDO relations are not synergistic, and what happens is the ego of each LDO in making work programs. It can see from the presence of several LDOs in coordination meetings not attended by the head of the LDO but only by staff.

\section{CONCLUSION}

$T$ he local government has made social policies to reduce the number of poor people. But the number of poverty figures is still high and tends to increase compared to the previous year. It is influenced by the social policy model that used not going well in the sense that it did not carry out consistently. The government has made social policies in an imperative and indicative model, including residual and institutional. But this model is not implemented systematically and organized in a synergistic and coordinative frame. It is due to several constraints, namely socialization of programs that not carried out comprehensively, the budget allocated for poverty programs is still very dependent on assistance from the center, placing people in program institutions often not according to competence, joining between LDOs is not going well. This condition must be changed to a superior program of the local government so that the composition of the budget directly touching the poverty program is no longer using indirect program terminology with poverty programs.

\section{E. ACKNOWLEDGMENT}

$\mathrm{T}$ hank you to LPPM UNAND for facilitating research through Kemenristekdikti's research grant funds years 2018. Likewise, undergraduate students, Rina and Linda, have helped to conduct interviews to make reports until the publication of this paper. 


\section{REFERENCES}

Andre $\beta$, Hans-Jurgen, and Thorsten Heien. 2001. Four World of Welfare State Attitudes? A Comparison of Germany, Norway, and The United States. Jurnal European Sociological Review, Vol. 17 No. 4, 337-356.

Andrianus Fery, Syafruddin Karimi dan Werry Darta Taifur. 2019. Inequality And Welfare Of The Displaced Households Due To The Construction Of Koto Panjang Dam. JURNAL ANTROPOLOGI: Isu-Isu Sosial Budaya, Vol. 21 No. 01, Juni, 93-102.

Basri dan Yoserizal. 2019. Identifikasi Faktor Pendorong Anak Perempuan Beraktivitas Di Jalanan (Suatu Studi Terhadap Anak Jalanan Perempuan di Kota Pekanbaru). JURNAL ANTROPOLOGI: Isu-Isu Sosial Budaya, Vol. 21 No. 01, Juni, 81-91.

Blau, Joel. 2003. The Dynamic of Social Welfare Policy. New York: Oxford University Press.

Caya, MUHPammad Fajar Nandra dan Ety Rahayu. 2019. Dampak BUMDES Terhadap Kesejahteraan Masyarakat di Aik Batu Buding, Kabupaten Belitung, Provinsi Bangka Belitung. Jurnal IImu Kesejahteraan Sosial, Jilid 20 Nomor 1, April, 1-12.

Gasper, Des. 2007. Human Well-being: Concepts and Conceptualizations. New York: Published PALGRAVE MACMILLAN.

Harkness, Susan. 2007. Social and Political Indicators of Human Well-being. New York: Published PALGRAVE MACMILLAN.

Kennett, Patricia. 2004. A Handbook of Comparative Social Policy. Northampton Massachusetts USA: Published Edwar Elgar

Lerner, K. Lee (ed). 2006. Social Policy; Social Issues Primary Sources Collection. USA: Thomson Gale

Lerner, K. Lee, Brenda Wilmoth Lerner, and Adrienne Wilmoth Lerner, Editors. 2006. Social Issues Primary Sources Collection Social Policy Essential Primary Sources. New York: Published Thomson Gale.

Lewis, Gail and Sharon Gewirtz and Jhon Clarke (ed). 2000. Rethinking Social Policy. London: SAGE Publication.

Lewis, Jane and Rebecca Surender. 2004. Welfare State Change: Toward Third Way ?. New York: Oxford University Press

Maolani, Dedeng Yusuf. 2019. Arah Kebijakan Sosial Perkotaan dan Pengurangan Kemiskinan di Perkotaan. Jurnal Kelola Vol. 2 No. 1, 104-120

McGillivray, Mark (ed). 2007. Human Well-Being: Concept and Measurement. New York: Published PALGRAVE MACMILLAN.

Nalle, Frederic W dan Emilia K. Kiha. 2018. Analisis Faktor-Faktor yang MempengarUHPi Tingkat Kemiskinan Di Kecamatan Insana Kabupaten Timor Tengah Utara (TTU). Jurnal Dinamika Ekonomi Pembangunan Vol. 1 No. 3, 35-45.

Nurwanda, Asep. 2019. Analisis Kebijakan Publik Terhadap Implementasi Kebijakan Pemerintah Desa LGRa Program Beras Sejahtera. Jurnal MODERAT, Volume 5, Nomor 1, Februari, 107120.

Page, Robert M. 2007. Introduction Social Policy: Revisiting The Welfare State. New York: McGraw Hill.

Ramdhani, Abdullah dan MUHPammad Ali Ramdhani. 2017. Konsep Umum Pelaksanaan Kebijakan Publik. Jurnal Publik, Vol. 11, No. 01, 1-12.

Rizal, MUHPammad Fikru dan Eddy Van Doorslaer. 2019. Explaining the fall of socioeconomic inequality in childhood stunting in Indonesia SSM - Population Health, 9, 1-10

Seeleib, Martin-Kaiser (ed). 2008. Welfare State Transformations: Comparative Perspectives. New York: Published Palgrave Macmillan.

Spicker, Paul, and Sonia Alvarez Leguizamon and David Gordon. (2007). Poverty An International Glossary Second Edition. New York: Published Zed Books.

Spicker, Paul. 2000. Welfare State A General Theory. New York: SAGE Publication.

Spiro, Shimon E and Ephraim Yuchtman-Yaar (ed). 1983. Evaluating the Welfare State Social and Political Perspectives. New York: ACADEMIC PRESS.

SUHParto, Edi. 2006. Analisis Kebijakan Publik : Panduan Praktis Mengkaji Masalah dan Kebijakan Sosial. Bandung : Penerbit Alfabeta 
Sutomo. 2011. Efektifitas Kebijakan Sosial dalam Pemecahan Masalah Sosial. Jurnal Ilmu Sosial dan Ilmu Politik, Volume 15, Nomor 1, Juli, 15-28.

Widodo, Joko. 2005. Analisis Kebijakan Publik : Konsep dan Analisis. Malang : Bayu Media Publishing Wulandari, Kusuma dan Evi Rosfiantika. 2018. POVERTY ALLEVIATION AND COMMUNITY WELFARE: A CASE STUDY IN BONDOWOSO REGENCY, EAST JAVA, INDONESIA. Asian Journal For Poverty Studies 4 (1), 1-6. 